\title{
THE NORTHERN SEA ROUTE AS A NEW ROUTE FOR MARITIME TRANSPORT BETWEEN THE FAR EAST AND EUROPE
}

\author{
Andrej Dávid ${ }^{1, *}$, Andrea Galieriková1, Jiří Tengler ${ }^{1}$, Vlatka Stupalo ${ }^{2}$ \\ ${ }^{1}$ University of Zilina, Zilina, Slovakia \\ ${ }^{2}$ University of Zagreb, Zagreb, Croatia \\ *E-mail of corresponding author: andrej.david@fpedas.uniza.sk
}

\begin{abstract}
Resume
Asian countries such as China, Malaysia, India or Bangladesh belong to the largest producers of consumer goods in the world that is mainly transported by container vessels to other parts of the world. One of the busiest maritime trade route is the route between Europe and Asia. It leads through the North Pacific, Indian and the North Atlantic Oceans and their seas. There is also an alternative trade route that runs along the coast of the Russian Federation across the Arctic Ocean. On one hand the ice in this area is gradually declining due to global warming, on the other hand the duration of navigation times is being extended for several months of the year. One of the advantages of this route is the reduction of sailing times between Asian and European maritime ports. The basic goals of the paper are to focus on the current transport situation on this trade route and a new trade route that leads along the coast of Russia.
\end{abstract}

Available online: https://doi.org/10.26552/com.C.2021.2.A74-A79

\section{Article info}

Received 11 May 2020

Accepted 27 May 2020

Online 17 December 2020

\section{Keywords:}

maritime transport, piracy, maritime trade routes, Northern Sea Route

\section{Introduction}

Maritime transport has got the biggest share in the cargo transport by seagoing vessels in the world. Asian countries such as China, India, Bangladesh or Vietnam have become the leaders in the production of consumer goods since the end of the 20th century. Brand mark companies that have got their headquarters in the developed countries situated in North America or Europe have moved their subsidiaries into developing countries located in Asia. These countries provide not only cheap labour force but also produce the goods that are accessible for most consumers from the point of view of price.

Transport of these goods takes a few weeks and seagoing vessels have to sail thousands of nautical miles. Most of these goods are transported into containers due to faster handling operation in the maritime ports and the protection of goods against stealing, loss or damage. In the last twenty years the volume of containers between Asia and Europe has increased more than four times. The old maritime trade route runs through the North Pacific Ocean, the South China Sea, the Strait of Malacca, the Indian Ocean, the Bab-el-Mandeb Strait, the Suez Canal, the Mediterranean Sea and the North Atlantic. There are some risk areas as the result of piracy.

There is also an alternative trade route (Northern Sea Route), which runs along the coast of the Russian Federation across the Arctic Ocean. On one hand global warming has led to a gradual ice decline in the region, on the other hand the voyage period has been extended to several months. This route is shorter than the old maritime trade route, but it still has some disadvantages such as the duration of navigation period or the dependence on the weather conditions. The basic goal is to focus on this route from the point of various criteria and to bring a new view on transport of cargo by maritime transport.

In the last few years the authors of the paper have performed their research that have been focused on transport of cargo by maritime transport between the Far East and Europe including the environmental changes in the Artic zone as the result of the global warming, their impact on traffic and transport of cargo including the legislation that regulates maritime transport and transport of cargo in this part of the world. The part of this research is also presented in this paper with emphasis on an alternative trade route between the Far East and Europe along the coast of the Russian Federation.

\section{Changing conditions in the Artic}

The Arctic is an area close to the North Pole. Its boundaries can be determined in various ways. It is either defined as the area in the north from the Arctic Circle, or as the area where the average temperature does not reach more than $10{ }^{\circ} \mathrm{C}$ even in the summer months. The Arctic Ocean is spread over most of the Arctic and it is completely covered with ice or partially thawed with floating hatchets 


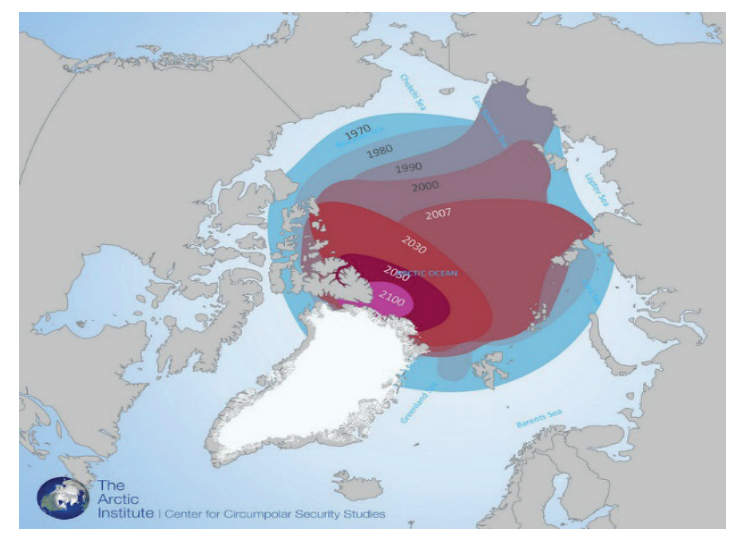

Figure 1 Development of Arctic glaciation for the period 1970 - 2100 [2]

for most of the year. The rest of the territory is made up of the northern parts of Asia, Europe and Greenland. The Arctic covers $8 \%$ of the earth's surface and due to climate change, the global warming is most pronounced here. The melting rate of glaciers is twice as originally expected. Since 1979 , the frozen area has decreased by up to $40 \%$. In 2012, there was the largest decrease in these areas. The frozen area was 14.5 million $\mathrm{km}^{2}$ in the area around the North Pole. It was approximately 1.1 million $\mathrm{km}^{2}$ less than the long-term average for the period 1981-2010. There is usually the most sea ice in February. The lowest measured value in this month was in 2015. Arctic ice will decrease by an average of $3.8 \%$ over a period of ten years. If this trend continues, in the second half of this century there will be no more ice in the Arctic during the summer. The following figure shows the level of glaciation since 1970. It can be seen that the ice surface is receding rapidly. In addition, it captures possible future developments until 2100, when the icy area in the Arctic is expected to be minimal and to reach only the northern part of Canada (Figure 1) [1].

International law states that no state owns the North Pole or the ocean in its immediate vicinity. However, there are the so-called "Arctic states", which include the USA, Russia, Canada, Norway and Greenland. Each of these states can claim an exclusive economic zone representing a marine area within a distance of $370 \mathrm{~km}$ from the coast. However, there are several contradictions as to whether other parts of the sea fall within areas belonging to national or international waters. The Arctic states also include Sweden, Finland and Iceland, despite extending into the area north of the Arctic Circle only in part of their territory. These states have been the core of the so-called Arctic Council, which is currently probably the most important international forum of the states of the Arctic region. Russia is considered the strongest player because it is investing tens of billions of US dollars (USD) to build infrastructure in the area. These are mainly investments in the mining industry. It is estimated that up to $95 \%$ of the Russian Federation's natural gas reserves and $60 \%$ of oil reserves are hidden in the Arctic. The Arctic region should hold as much as $25 \%$ of the world's oil and gas reserves. The local waters are also rich in other sources of mineral wealth such as phosphates, iron ore, nickel, cobalt, copper, uranium and gold. Due to climate change, the extraction of raw materials in this area is becoming more and more achievable. In addition to Russia, China is also interested in local mining opportunities, as it is one of the world's major importers of the raw materials. There are two benefits to extending the period of ice melting in the Arctic. The first is availability of minerals for mining companies, the second is the possibility of these companies to use one of the offered sea routes for transport of the raw materials [3].

As the results of the changes mentioned above, the authors suggest updating the present legislation that regulates maritime transport in the Artic zone. On one hand these changes may stimulate maritime transport and transport of cargo in this part of the world. On the other hand, they may influence development of environment negatively such as an accelerated process of melting of icebergs or harmful impact on the animals living in in this part of the world. A lot of animals that live there are on the edge of extinction.

\section{The main trans - Arctic routes}

A global warming in the area around the North Pole offers new opportunities from the point of maritime transport. The parts of the Arctic may become more reliable for navigation during the summer months of the year. The term "major trans-Arctic routes" includes the Northwest Passage (NWP) and the Northeast Passage (NEP).

While on the NWP is one of the possible routes connecting the Pacific and Atlantic Oceans along the Canadian coast, NEP is any sea route connecting Europe and Asia bordering the northern coasts of Norway and Russia (Figure 2).

The Northwest Passage is not as easily accessible as the Northeast Passage. This is mainly due to the wider ice cover of the Canadian islands in the Arctic. Another reason is the almost non-existent infrastructure and commercial transport. Only $10 \%$ of this area is sufficiently mapped, so any activity in this area is more for research purposes. In 2011, only 26 vessels used this route, but none of them carried cargo [5]. An alternative route for the Northwest Passage is a route through the Panama Canal. The Northeast 


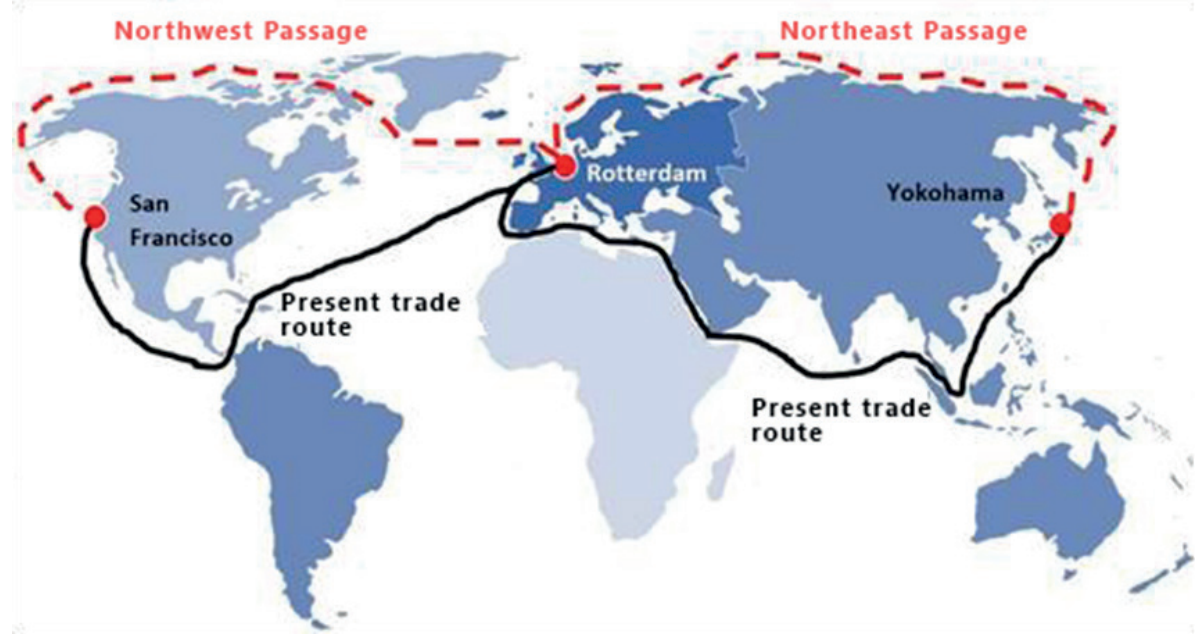

Figure 2 The main trans-Arctic routes (comparison) [4], adapted by authors

Passage could compete with the shipping route leading through the Suez Canal. At on the first glance, a significant difference in distances is visible. In both cases, the route through the Arctic is significantly shorter than the present shipping routes. The NWP is $7,000 \mathrm{~km}$ shorter than the Panama Canal route, the length of NEP is two-thirds that of the traditional Suez Canal route. Shorter distances mean shorter transport times, fuel consumption and costs.

The Northern Sea Route is a shipping route that runs along the Russian Arctic coast from the Kara Sea, along Siberia, to the Bering Strait. While on the NEP includes all the East Arctic seas and connects the Atlantic and Pacific oceans, the Northern Sea Route does not include the Barents Sea and it therefore does not reach the Atlantic.

\section{The Northern Sea Route}

The Northern Sea Road runs along the Siberian coast. The routes leading through this area connect Russian ports, Far Eastern ports and the mouths of Siberian navigable rivers into one transport system. The North Sea Route begins in the Barents Sea and ends in Providence Bay.

Recently, the situation around this route has begun to change rapidly. Due to the effects of global warming, the navigation period of vessels has increased significantly. Whereas in the past the navigation period lasted from July to September, it currently lasts from June to November. In addition, several factors need to be taken into account that may attract the attention of foreign companies in this direction in the coming years:

1. The average delivery time through the Suez Canal is 48 days and the route across the Arctic seas is 35 days, i.e. consequently, delivery times, fuel and transport costs are significantly reduced and saved.

2. There are no delays and fees for the passage of vessels (unlike the Suez Canal). The only charge is use of an icebreaker, which navigates this route.

3. Absence of illegal actions (pirate raids).

4. No restrictions on vessels related to their size and tonnage [6].

\subsection{The arising risks during the cargo ship voyages}

A big problem in implementation of voyages on these routes is the equipment of ships. Most of today's vessels are not capable of navigating in the Arctic conditions. Even in the periods when the route is navigable, the terrain remains unpredictable and very dangerous. Only special vessels that are able to withstand local conditions are adapted to navigate in the difficult conditions. Navigation in the Arctic is not just about making the route through the frozen or semi-frozen ocean. It also involves very demanding planning. To avoid the high pressure on the hull, it is necessary to choose a route that avoids the hidden ice stream. An experienced captain should be present during the voyage to avoid an adverse situation due to the human factor. Most ships passing through the Arctic cannot be accompanied by icebreakers throughout the journey. Russia and Canada use icebreakers only in the most frozen parts of the Arctic sea routes, due to their high costs. Therefore, passing ships are at great risk (hidden glaciers). In the event of a collision, there is a high chance for a disaster, due to the fact that there are currently not enough rescue services in the Arctic [7-8].

Development of the maritime transport in the Arctic is hampered by a number of factors, such as short voyage time during the year, unpredictability of ice, high costs of sailing with icebreakers and costs of permitting navigation along the Russian coast, absence of a sufficient number of ships capable of sailing in frozen areas and the high costs of risk insurance. This is especially true for the container transport, for which regular crossing of the North Sea Road is still in sight. For development of the container transport in this area, it is necessary to increase shipping traffic so that consignments can be consolidated. Due to implementation of a lower number of cruises in this area, this is not possible. Therefore, the costs remain higher.

The weaknesses in the current maritime route from China to Europe are beginning to manifest with the growth of international trade. On one hand there are pirate attacks on this route. On the other hand, the Suez Canal is often congested and vessels wait several hours. Development of 


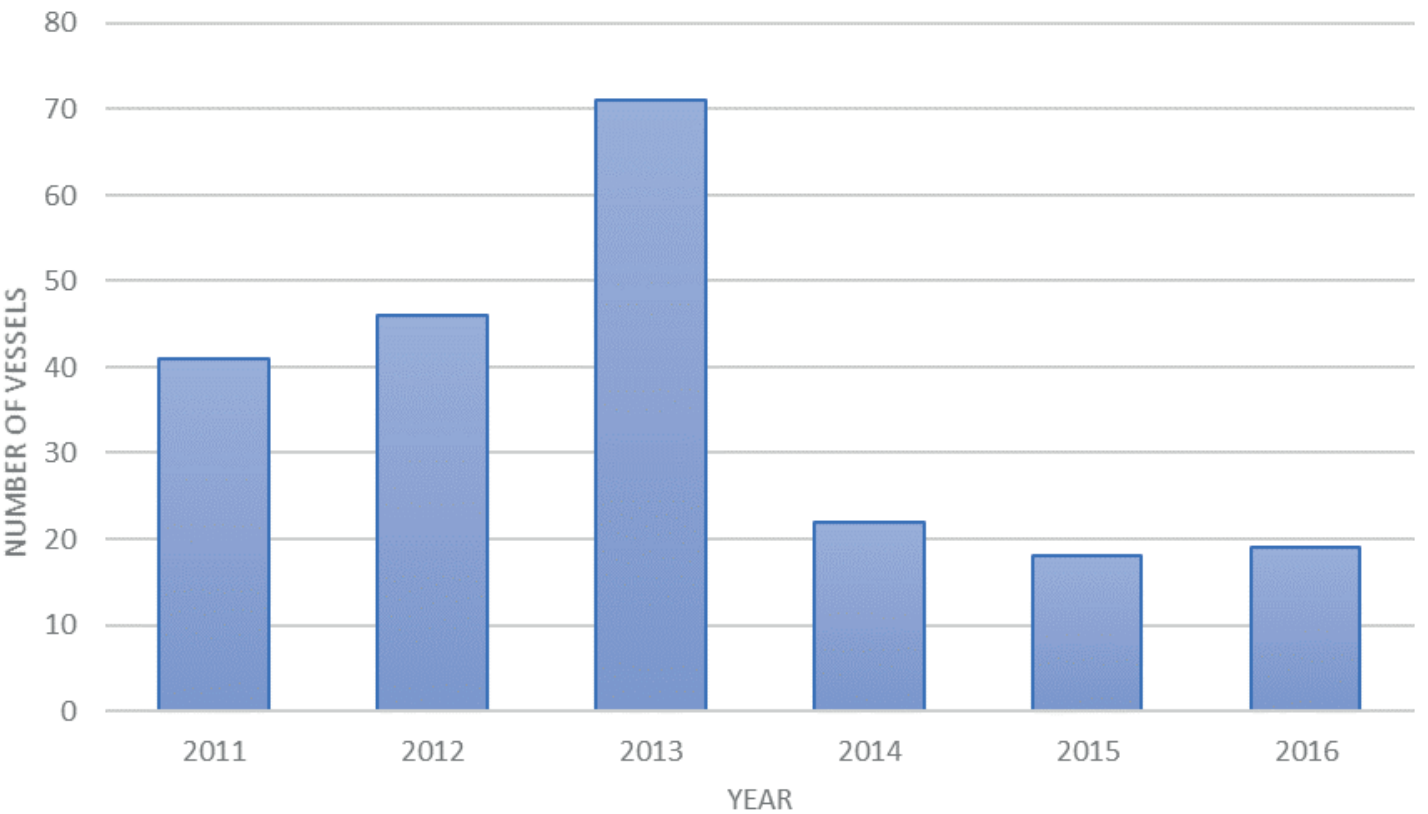

Figure 3 The number of vessels that passed through the Northern Sea Route between 2011 and 2016 [2]

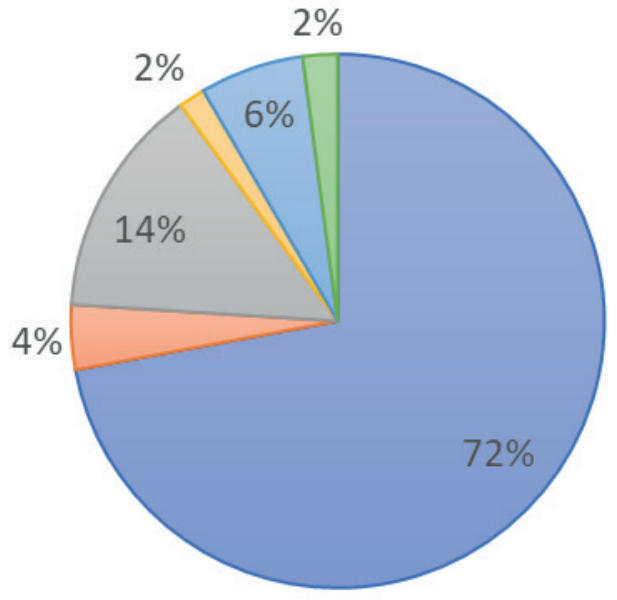

口Coal

$\square$ Oil products

$\square$ Paper

$\square$ Frozen meat and fish

$\square$ Iron ore

a General cargo

Figure 4 Type of cargo transported on the North Sea Road in 2016 [2]

the North Sea Route is a multilateral project, which will also contribute to the socio-economic recovery of the northern regions of Russia. As a result, Russia could increase its share of international commodity markets in this area. The Northern Sea Route is the only link in the Arctic region between Russia's subarctic and Arctic regions. It has a great influence on development of the north of Russia [7].

Analysts estimate that the route along the Russian coast has a throughput of about 50 million tons per year [8]. This route is becoming more popular every year. The reason is the growing activity of oil and gas companies in the Arctic. Private investors also play a major role. Until 2000, Russia paid little attention to Arctic infrastructure. However, the government has recently taken active steps in this direction. Russia aims to regain its former dominance in the Arctic. In 2008, Russia adopted the "Strategy for Development of the Arctic Region of the Russian Federation until 2020", in which the Arctic acts as a key strategic territory of the country. The main objectives of this strategy are:

- creation of a common transport area,

- more involvement in the global transport chain while making maximum use of its own transport routes,

- provision of affordable and quality transport services,

- reducing the negative environmental impacts in the Arctic.

Development of the transport infrastructure and transportation in this area can have a positive impact on the Russian economy. The interest in the development of the North Sea Route in Russia is also due to the fact that it owns by far the largest fleet of icebreakers in the world. It can get big money for renting them. Japan is also interested in participating in the development of this route. Due to the location of this country, its use is more important than for other states. For Japan, this is the fastest way to deliver 
goods to Europe. The Japanese estimate that up to $40 \%$ of their goods imported into Europe should be exported through this route. In addition to Japan, China is also interested in the area, which has its own ground program called the "Silk Road" [9].

\subsection{Transport of cargo}

Arctic maritime routes allow more efficient, shorter and several times faster transport between the Far East and Europe. There are big differences in transport statistics (Figure 3). While in 2010, the fewest vessels passed through this area (only four vessels), in 2013, 71 vessels passed through the Arctic. In 2014, there was a significant decrease, only 25 ships crossed the Russian coast. In 2016, 19 ships crossed the route. These vessels carried approximately 214,500 tons of cargo. This route had the greatest expansion in 2017, when up to 9.7 million tons of cargo were transported. The stagnant development of maritime transport in the Arctic is mainly attributed to difficult natural conditions and shipping companies, which perceive it as unprofitable.

In 2016, the most coal was transported on this route (154,522 tons), which represented up to $72 \%$ of the total transported cargo (Figure 4). The second most important item was paper (30,042 tonnes), about $14 \%$ of the total. Other commodities were also transported here, the volumes of which were not as extensive as in the previous cases. These were mainly iron ore, petroleum products, piece cargo, frozen meat and fish

\section{Discussion}

As the result of the carbon burning the humanbeing has been producing harmful gases (carbon dioxide or methane) that influence the gradual raising of the atmosphere temperature, consequent iceberg melting and sea level rise. If the human-being does not reduce the pace of production of these gases, in a near future we will face gradual flooding of some parts of the world, population migration or extinction of some animal species.

In spite of the changes that have happened in the construction of new engines that use fuels with lower level of sulphur, nitrogen and carbon, the maritime transport, especially the sea going vessels, also belong to the biggest producers of these harmful gases. Maritime transport has had the biggest share in transport of all the types of cargo between the continents in comparison to other modes of transport. The ship-owners have optimized the cargo ship voyages due to faster cargo delivery, reducing of transport costs and profit maximization. They have also tried to find new alternative ways how to transport cargo.

The Northern Sea Route that leads along the coast of the Russian Federation could become a new trade and transport route between the countries of the Far East and the European Union. The former Soviet Union used it for transport of raw materials extracted in the Artic zone. The navigation time has been prolonged in this part of the world as a result of the global warming. In the near future, shipowners could use it due to faster cargo transport between Europe and Asia. On the other hand, these voyages could have negative impact on the environment in the Artic zone in the form of faster iceberg melting and extinction of some animal species. The humans should consider what is more advantageous for them.

\section{Conclusions}

It will take about another two decades for the North Sea Road to be integrated into the main maritime trade routes. In spite of the fact this route is a shorter route than the present trade route that leads the Far East and Asia, one of the biggest disadvantages of this route is the fact that there is no possibility of rescue in the case of a dangerous situation. The Russian Federation is trying to build nine rescue centres that could help in the accident events. Each of these centres will be equipped with helicopters, fire and rescue services. The plan also includes the construction of thirty automated observation stations and weather monitoring equipment [10].

The Russian government's forecasts are very positive. They expect the volume of cargo transported in this area to increase by $20 \%$ over the next 15 years. This would mean an increase of more than 80 million tons of cargo. However, after many analyses, this development seems slightly exaggerated. Especially for the container transport, such estimates are unrealistic. Some experts believe that this route will be mainly the international transport of hydrocarbons in the future.

Using this route eliminates the problem of piracy, which occurs mainly in the Straits of Malacca, the island of Sumatra or the Gulf of Aden. There are also no narrowed places or canals up to the Bering Strait. The biggest shortcoming of the North Sea Road is the lack of infrastructure for regular voyages. Development of transport in the Arctic could also be prevented by various groups of animal welfare workers. If regular transports took place in the Arctic, it could have a negative impact on the local ecosystems and the melting of glaciers. Therefore, some environmental organizations are very critical of the use of this route.

Based on the latest estimates, it is estimated that in 15 to 20 years, the North Sea Road would be used throughout the year. At present, the interest of carriers for its use is rather declining. It may take several more decades for a regular liner shipping route to operate here. The container transport is already technically possible, but not so economically advantageous.

The main advantage of this route is that the transport time and distance is shorter, but the fees associated with implementation of transport are higher. In addition to the Russian Federation, China also plans to transport 5 to $15 \%$ of its cargo via the container route over the next ten years [11-12]. However, despite the major shortcomings, 
the North Sea Road has its advantages. If the price of oil increases, the usability of the northern sea route may increase sharply [13-14]. The following facts need to be resolved for the successful development of this route:

- the authorization process for the passage of vessels through this area - the decision should be clear and comprehensible to the carrier,

- the need to introduce uniform rates for transport along the entire North Sea route,

- $\quad$ it is necessary to attract the world's major shipping companies so that they can take part in the planning of vessels operating on Arctic routes,
- establishing coordination of work of all the ports through which the North Sea Road passes.

\section{Acknowledgements}

The paper is supported by the VEGA Agency by the Project 1/0798/21 "The Research on the Measures to Introduce Carbon Neutrality in the Rail and Water Transport" that is solved at Faculty of Operation and Economics of Transport and Communications, University of Zilina.

\section{References}

[1] JANSKY, B. Impact of Climate Changes on the Arctic / Vliv klimatickych zmen na Arktickou oblast (in Czech). Geograficke rozhledy [online] [accessed 2020-05-10]. 2011, 5(10-11), p. 22-25. ISSN 1210-3004. Available from: https:// www.geograficke-rozhledy.cz/archiv/clanek/506/pdf

[2] Russian PM orders to increase Northern Sea Route capacity by 20 times [online] [accessed 2019-05-10]. Available from: https://www.rt.com/business/265756-northern-sea-route-medvedev/

[3] The emerging artic - Council on foreign relations [online] [accessed 2019-03-18]. 2014. Available from: http://www.cfr. org/polar-regions/emerging-arctic/p32620\#!/?cid=otr_marketing_use-arctic_Infoguide\#!

[4] World map [online] [accessed 2019-03-11]. Available from: https://en.wikipedia.org/wiki/File:World_Map_WSF.svg. png

[5] Short and sharp - The economist [online] [accessed 2019-01-28]. 2012. Available from: http://www.economist.com/ node/21556803

[6] The Northern Sea Route [online] [accessed 2019-02-18]. 2017. Available from: https://xsreality.org/sk/severnyjmorskoj-put-severnyj-morskoj-put-ego-osvoenie-i-razvitie-vyzyvaet-bolshoj-interes-uchenyh-issledovatelejnashej-strany-i-zarubezhnyh-spetsialistov-ego-istoriya-eto-interesnejshie-ekspeditsi/

[7] GEORGESCU, C. Northern Sea Route. Knowledge Horizons - Economics [online] [accessed 2019-03-19]. 2014. Available from: http://www.orizonturi.ucdc.ro/arhiva/2014_khe_6_pdf4/georgescu_1.pdf

[8] BAMBULYAK, A., EHLERS, S. Oil spill damage: a collision scenario and financial liability estimations for the Northern Sea Route area. Ship Technology Research [online]. 2020, 67(3), p. 148-164. ISSN 0937-7255, eISSN 2056-7111. Available from: https://doi.org/10.1080/09377255.2020.1786932

[9] WANG, D., DING, R., GONG, Y., WANG, R., WANG, J., HUANG, X. Feasibility of the Northern Sea Route for oil shipping from the economic and environmental perspective and its influence on China's oil imports. Marine Policy [online]. 2020, 118, 104006. ISSN 0308-597X. Available from: https://doi.org/10.1016/j.marpol.2020.104006

[10] The Northern Sea Route Facts - Arctic-lio [online] [accessed 2019-03-18]. 2016. Available from: http://www.arctic-lio. com/nsr_transits

[11] The Most Ambitious Chinese Megaproject Mapped - a New Silky Road - Financial market [online] [accessed 2018-0118]. 2018. Available from: https://www.financnytrh.com/najambicioznejsi-cinsky-megaprojekt-zmapovany-novahodvabna-cesta/

[12] BENNETT, M. The Northwest Passage versus the Northern Sea Route [online] [accessed 2019-01-19]. 2011. Available from https://cryopolitics.com/2011/08/19/the-northwest-passage-versus-northern-sea-route/

[13] Arctic shipping. Position paper - ICS [online] [accessed 2019-03-07]. 2014. Available from http://www.icsshipping.org/ docs/default-source/resources/policy-tools/ics-position-paper-on-arctic-shipping.pdf?sfvrsn=20

[14] JURKOVIC, M., KALINA, T., SOSEDOVA, J., TVRDA, E. Globalisation of the LNG trade in Caspian region. In: 16th International Scientific Conference Globalization and its socio-economic consequences: proceedings. University of Zilina. 2016. ISBN 978-80-8154-191-9, ISSN 2454-0943, p. 793-799. 